\section{Short-term Storage of Almond Pollen}

\author{
P. Martínez-Gómez and T.M. Gradziel \\ Department of Pomology, University of California, Davis, CA 95616
}

\section{E. Ortega and F. Dicenta}

Departamento de Mejora y Patología Vegetal, Centro de Edafologia y Biologia Aplicada del Segura-Consejo Superior de Investigaciones Cientificas, P.O. Box 4195, E-30100 Murcia, Spain

Additional index words. Prunus dulcis, pollen germination, temperature

Abstract. Almond [Prunus dulcis (Mill.) D.A. Webb] breeding programs require successful techniques for pollen storage. We studied the pollen viability of two almond cultivars, 'Ramillete' and 'Desmayo Largueta', during 8 weeks of storage, in conditions that simulated standard situations including storage at 4,22 , and $4{ }^{\circ} \mathrm{C}$ alternating with $22{ }^{\circ} \mathrm{C}$ $\left(4{ }^{\circ} \mathrm{C} / 22{ }^{\circ} \mathrm{C}\right)$. Viability remained at $60 \%$ or more for 2 weeks under all three conditions. After the second week, germination capacity decreased rapidly at $22{ }^{\circ} \mathrm{C}$, but remained above $50 \%$ for as long as 8 weeks at $4{ }^{\circ} \mathrm{C}$ or $4^{\circ} \mathrm{C} / 22{ }^{\circ} \mathrm{C}$.

Most almond cultivars are self-incompatible and late-flowering cultivars may bloom as much as 6 weeks after early ones (Dicenta, 1991). Usually, the pollen is collected and dried before pollination of the female parent and the differences among cultivars in flowering time often require pollen storage. Adequate dehydration and low storage temperatures are crucial for maintaining viability (Cobo, 1980; Visser, 1955).

Pollen viability can be assessed by germination and growth in a sugar and agar medium. This technique can determine the influence of external conditions on germination and subsequent pollen tube growth (García, 1978; García and Egea, 1979; Hill et al., 1985; Parfitt and Almehdi, 1984). The results of such in vitro germination assays agree with those obtained in vivo by recording fruit set (Klungness et al., 1983; Loreti et al., 1979).

Our objective was to determine the viability of the pollen of two almond cultivars stored under three different temperature conditions.

\section{Materials and Methods}

Cultivars. The pollen of two Spanish almond cultivars, 'Ramillete' and 'Desmayo Largueta', which previously showed a high in vitro germination capacity (García, 1978; García and Egea, 1979), was evaluated.

Storage conditions. The pollen was collected and dehydrated for $48 \mathrm{~h}$ at $22{ }^{\circ} \mathrm{C}$ in a desiccator with calcium chloride [approximate relative humidity $(\mathrm{RH})$ of $20 \%]$. Samples

Received for publication 12 Nov. 1999. Accepted for publication 7 Feb.2000. The authors thank the Spanish Ministry of Education and Culture for supporting the stay of Pedro Martínez-Gómez in the United States. This work has been funded through the project "Mejora Genética del Almendro" (AGF98-0211-C03-02) from the "Plan Nacional de I+D" of the Spanish Ministry of Education and Culture. The cost of publishing this paper was defrayed in part by the payment of page charges. Under postal regulations, this paper therefore must be hereby marked advertisement solely to indicate this fact.

HortScience, Vol. 35(6), October 2000 storage. A fine paint brush was used to deposit the pollen on the surface of the agar in a petri of $\approx 0.5 \mathrm{~g}$ were stored for 8 weeks in hermetically sealed $25-\mathrm{mL}$ glass vials $(\mathrm{RH} \approx 30 \%)$ at 4 ${ }^{\circ} \mathrm{C}, 22{ }^{\circ} \mathrm{C}$, or at $4{ }^{\circ} \mathrm{C}$ for $18 \mathrm{~h}$ and $22{ }^{\circ} \mathrm{C}$ for 6 $\left(4{ }^{\circ} \mathrm{C} / 22^{\circ} \mathrm{C}\right)$ each day.

In vitro germination of pollen. Pollen dish containing $25 \mathrm{~mL}$ of culture medium (15\% sucrose, $1.2 \%$ agar) (García, 1978; García and Egea, 1979; Parfitt and Almehdi, 1984; Remy, 1953) using one dish per treatment. The petri dishes were incubated at $22^{\circ} \mathrm{C}$, the optimum temperature for the in vivo growth of almond pollen tubes (Socías, 1974) for $6 \mathrm{~h}$ to obtain maximum germination (García and Egea, 1979). Pollen germination was observed using an optical microscope at $40 \times$ and was considered to have occurred when the length of a pollen tube exceeded its diameter (Ducon, 1968). Longer incubation periods produced more growth of pollen tubes but not higher percentages of germination (García, 1978).

Statistical analysis. Eight different fields of vision, each with an area of $12.5 \mathrm{~mm}^{2}$, and $\approx 250-300$ pollen grains per field were examined per dish. Each count was considered as one replicate. A two-way analysis of variance was performed on the percentage germination using the SAS statistical analysis package (SAS Institute, 1989). Means were separated by Tukey's multiple range test at $P \leq 0.05$.

\section{Results and Discussion}

No significant differences were observed between 'Ramillete' and 'Desmayo Largueta' under the different pollen storage conditions. However, significant differences were ob-
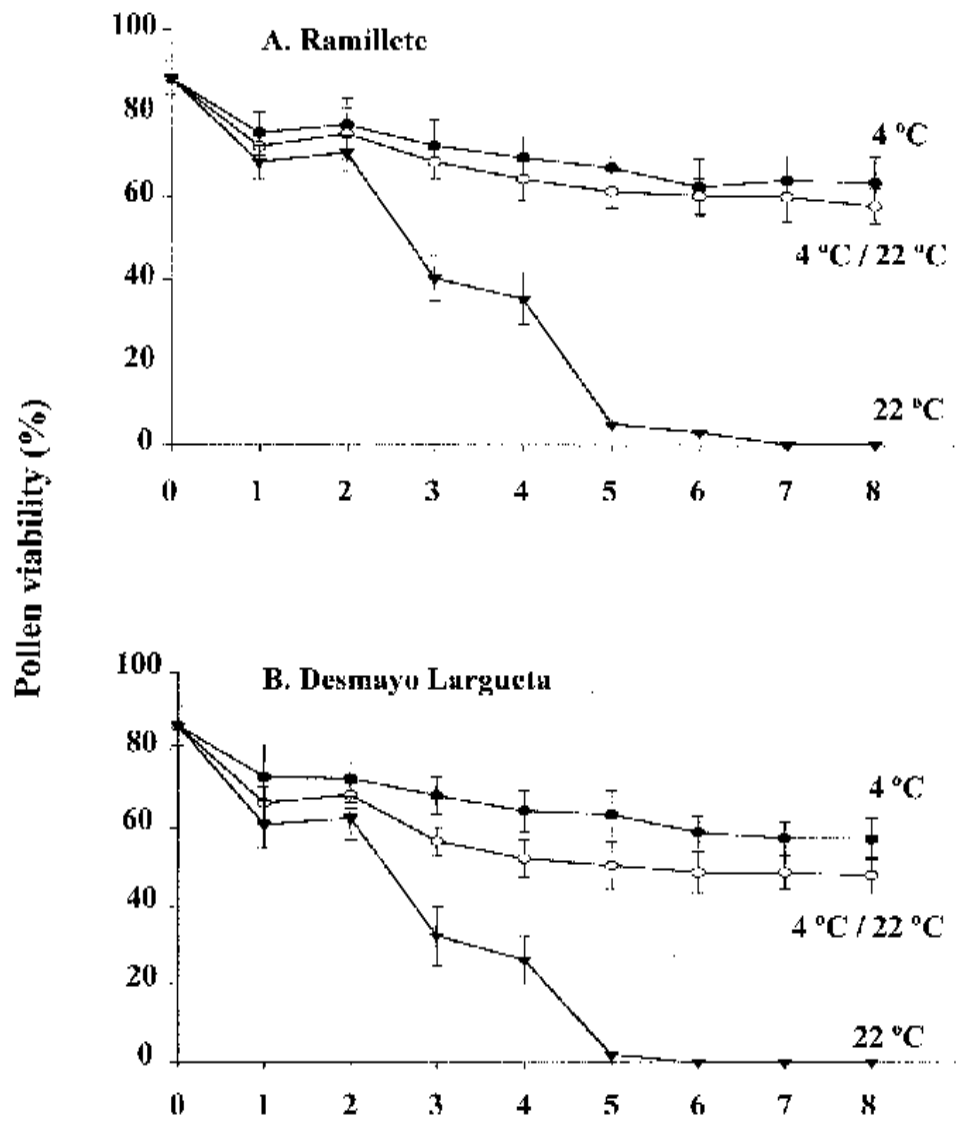

Time (weeks)

Fig. 1. Effect of temperature on time course of pollen viability of almond cultivars Ramillete and Desmayo Largueta during 8 weeks of storage. Bars show standard deviation about mean. 
served among storage conditions for both genotypes (Fig. 1). Pollen viability at the beginning of storage (just after drying) was $88.3 \%$ in 'Ramillete' and $86.2 \%$ in 'Desmayo Largueta', which is similar to previous results (García and Egea, 1979). These percentages can be considered high with respect to the in vitro germination rates of typical almond cultivars, which ranged from $12 \%$ to $95 \%$ in other assays (García and Egea, 1979; Hill et al., 1985; Klungness et al., 1983; Loreti et al., 1979; Parfitt and Almehdi, 1984). For both cultivars, the change in pollen viability with time was similar for all three conditions assayed (Fig. 1 ). Beginning at $\approx 2$ weeks, the viability of the pollen stored at $4{ }^{\circ} \mathrm{C}$ and at $4 / 22^{\circ} \mathrm{C}$ decreased gradually until week 8 , when germination at 4 ${ }^{\circ} \mathrm{C}$ and $4 / 22{ }^{\circ} \mathrm{C}$ was $63.2 \%$ and $57.5 \%$ ('Ramillete') and 57.2\% and 47.8\% ('Desmayo Largueta'), respectively. Viability during storage at $22^{\circ} \mathrm{C}$ fell sharply after the second week to become almost nil by week 5 (Fig. 1). This strong influence of temperature on stored pollen viability has been mentioned by several earlier authors (Cobo, 1980; Parfitt and Almehdi, 1984; Visser, 1955) . Not only did the germination percentage of pollen stored at $22^{\circ} \mathrm{C}$ drop sharply, but the rate of pollen tube growth was also reduced; this became more pronounced with time. The color of the pollen also faded after week 2 (data not shown).

In conclusion, pollen stored at $4{ }^{\circ} \mathrm{C}$ was viable for 8 weeks or longer. Exposure to 22 ${ }^{\circ} \mathrm{C}$ for $6 \mathrm{~h}$ per day did not significantly reduce viability during 8 weeks of storage. We conclude that pollen can be sent to other research centers at room temperature and remain viable provided transport takes no more than 2 weeks.

\section{Literature Cited}

Cobo, A. 1980. El polen. Recogida, manejo y aplicaciones. Hoja Divulgadora 8/80. Ministerio de Agricultura, Pesca y Alimentación, Spain.

Dicenta, F. 1991. Mejora genética del almendro (Prunus dulcis Miller) por cruzamientos intervarietades: Herencia de caracteres y selección. PhD Diss., Univ. de Murcia, Spain.

Ducon, P. 1968. La fructification des arbres fruitiers. Etude de quelques caractères du pollen et de la biologie florale de l'Amandier et Pommier. Pomologie Française 5:11-42.

García, J.E. 1978. Biología floral en variedades cultivadas de almendro (Prunus amygdalus Batsch). PhD Diss., Centro de Edafologia y Biologia Aplicada del Segura-Consejo Superior de Investigaciones Cientificas, Murcia, Spain.
García, J.E. and L. Egea. 1979. Influencia de la temperatura en la germinación del polen de variedades de almendro. Ann. de Edaf. Agrobiología 38:2181-2193.

Hill, S.J., D.W. Stephenson, and B.K. Taylor. 1985. Almond pollination studies: Pollen production and viability, flower emergence and cross-pollination tests. Aust. J. Expt. Agr. 25:697-704.

Klungness, R., R. Thorp, and D. Briggs . 1983. Field testing the germination of almond pollen (Prunus dulcis). J. Hort. Sci. 58:229-235.

Loreti, F., R. Viti, and C. Xiloyannis. 1979. Prove di impollinazione incrociata e fertilità del polline di alcune cultivar di mandorlo. Frutta secca 116:379-391

Parfitt, D.E. and A. Almehdi. 1984. Liquid nitrogen storage of pollen from five cultivated Prunus species. HortScience 19:69-70.

Remy, P. 1953. Contribution a l'etude du pollen des arbres fruitiers noyau, gen. Prunus. Ann. Amelioration des Plantes 3:351-388.

SAS Institute. 1989. SAS/STAT user's guide. SAS Inst., Cary, N.C.

Socias, R. 1974. Effect of temperature and genotype on pollen tube growth of some self-compatible almond selections derived from peach (Prunus persica L.) and almond (Prunus amygdalus Batsch.) hybridization. PhD Diss., Univ. California, Davis.

Visser, T. 1955. Germination and storage of pollen. Landb. Wageningen 55:5-68. 